\title{
The effect of financial inclusion on micro, small, and medium enterprise performance using fintech as a moderating variable
}

\author{
K. Efan, S.R. Basana, \& R.S.D. Ottemoesoe \\ Faculty of Business and Economics, Petra Christian University, Surabaya, Indonesia
}

\begin{abstract}
Financial inclusion can reduce social disparities and poverty and increase economic growth and national financial efficiency. Access to financial services is provided to all segments of the society. Currently, MSMEs are still experiencing difficulties in terms of capital. Access to financial services in banking is also still difficult due to the lack of financial information on the MSMEs when compared to large, more transparent companies; thus, banks have more difficulty in assessing the creditworthiness of MSMEs. This study examines the influence of financial technology (fintech), which is developing rapidly in Indonesia. The variables used in this study are financial inclusion, MSME performance, and the use of fintech e-payment as moderating variables. The results revealed that financial inclusion has a relationship with the performance of MSMEs. Financial inclusion encourages people to access financial products, and people can more freely use their money to make transactions. The fintech variable does not have a moderating effect on the relationship between financial inclusion and MSME performance.
\end{abstract}

\section{INTRODUCTION}

Financial inclusion is public access to financial services by increasing the reach, quality, and availability of the existing financial services. Indonesian Bank (BI) explains that this financial service is provided to all segments of society, especially the poor and low-income people, the productive poor workers, migrant workers, and people living in remote areas. According to data from the Otoritas Jasa Keuangan (OJK/Financial Service Authority), as many as 54 million Indonesians are still not reached by conventional financial services, such as banks, which means that many people do not have a bank account (Ramadhani, 2020). Currently, MSMEs are still experiencing difficulties in terms of capital. Enny Sri Hartati, who is the Director of the Institute for Development of Economics and Finance, explained that capital is one of the main obstacles faced by MSMEs with a percentage of $60 \%$ (Firdaus, 2020). Access to financial services in banking is still difficult due to the lack of financial information on MSMEs when compared to large, more transparent companies, so banks have more difficulty in assessing the creditworthiness of MSMEs and providing loans to MSMEs. Sometimes, the owners of MSMEs have difficulty in making good financial records/bookkeeping, and thus, it is not easy for banks to carry out risk assessments and creditworthiness. Thus, MSMEs can fail to fulfill the number of orders or consumer requests due to a lack of production capital (Setyadi, 2017).

The financial sector in Indonesia is quite developed based on the emergence of many financial technology-based startup companies, or commonly referred to as fintech in recent years (Ardela, 2017). According to BI, the state benefits from the existence of fintech, for example, by encouraging economic policies, increasing the velocity of money, improving the people's economy, and promoting a national financial inclusion strategy. Fintech increases financial inclusion by providing responsible and sustainable access for individuals and businesses to financial products and services such as transactions, payments, savings, credit, and insurance (Batunanggar, 2019). This study examines the effect of financial inclusion on the performance of MSMEs in Surabaya City. It focuses on MSMEs engaged in the food and beverage sector; this sector absorbs $50 \%$ of the 
household income (Setiawan, Emvalomatis, \& Lansik, 2012). This study examines the impact of using fintech e-payment on the relationship between financial inclusion and MSME performance. The rapid development of fintech, especially in Indonesia, is worth researching because fintech can increase the development of new companies, facilitate financial services by streamlining energy and time, and support national financial inclusion (Ramadhani, 2020).

\section{RELATIONSHIP BETWEEN RESEARCH CONCEPTS}

Chauvet and Jaolin (2017) explain that financial inclusion or public access to financial services is beneficial for all types of businesses, and it affects the growth of a business. According to Agnello, Mallic, and Sousa (2012), financial inclusion contributes to economic growth. In addition, Kodan and Chhikara (2013) also found a relationship between financial inclusion and literacy and per capita income (economic growth). These findings show that with a good level of financial inclusion, there will be growth in per capita income, which will be reflected in MSMEs' income. The research conducted by Yanti (2019) explains that the MSME performance will increase if they continue to increase financial inclusion. The increase in financial inclusion or access to banking products will help MSMEs to obtain funds that can be used for business capital, daily needs, expansion, and reserve funds for the future of these MSMEs. Therefore, the first hypothesis is as follows:

H1: Financial inclusion affects the performance of MSMEs.

The research conducted by Rahmi (2018) explains that financial inclusion in Indonesia requires fintech to accelerate its progress in the digital era. By embracing fintech, it will provide great assistance for the Indonesian government to achieve the Go Digital Vision 2020 goals (Rahmi, 2018). The research conducted by Kunt et al. (2013) explains that digital technology can increase financial inclusion; thus, people who are not eligible to take loans from banks will enjoy greater access to financial facilities with fintech. This is supported by the research on the case of microloan startup companies conducted by Leong et al. (2017), where fintech can increase financial inclusion of people who take loans from fintech companies. Fintech reaches out to parties that have been neglected by banks and provides better service to the banks' customers (Batunanggar, 2019). Changing cellular technology has opened opportunities and enabled nearly three billion people without bank accounts to access financial services (Iman, 2018). The research conducted by Soriano (2017) on start-up fintech companies explains that company founders, who have experience using financial services, are customer-oriented (customer-centricity), and have strategic partnerships with financial institutions and e-commerce companies, have a positive correlation with financial inclusion (measured by active customers) and financial performance (measured by annual revenue). Fintech will encourage people to have a bank account before using its services. Afterward, they can use or get services such as payment/credit easily. In addition, by using fintech, there will be data that can be used by banks or other institutions to evaluate the feasibility of providing credit. This financial service will be used to improve its performance in the present and as a reserve fund for the future.

$\mathrm{H} 2$ : The use of fintech services moderates the relationship between financial inclusion and MSME performance.

\section{METHODS}

The population used in this study was the MSMEs in Surabaya City. The research sample was selected using the non-probability sampling technique employing purposive sampling. The sample criteria included in this study were MSME owners/managers engaged in the food and beverage sector and using fintech e-payment services. This study used a questionnaire as a way of collecting the data. The questionnaire contains optional questions to obtain information from the respondents. Each question is given a score from 1 (strongly disagree) to 5 (strongly agree). The analysis process 
carried out in this study was to collect research data by distributing questionnaires to the respondents in order to meet the target sample size required and process the data from the questionnaire that had been obtained by testing the outer model, inner model, and hypothesis testing using the SEM with SmartPLS version 3.0 software.

\section{FINDINGS AND DISCUSSION}

The respondents in this study were MSMEs in Surabaya City engaged in the food and beverage sector. The research data were obtained using a questionnaire that was distributed online to the respondents via the Google Form link, namely, MSME actors who live in Surabaya City who use fintech e-payment services. However, 32 questionnaires did not match the specified criteria; thus, the questionnaires that met the processing requirements were only 84 questionnaires.

Overall answers regarding financial inclusion statements obtained a mean value of 4.57 . The respondents made financial transactions more than twice in a month by looking at the mean of the statement of depositing or withdrawing money at least twice in a month, namely, 4.02 and 4.11. In addition, banks and their facilities are already available in various places, making them easily accessible to the public. Furthermore, the respondents' overall answers regarding the use of fintech e-payment obtained a mean value of 4.36. The respondents felt that the fintech epayment service was easy to use, indicated by the mean of the statement of the ease of learning, operating, understanding, and mastering the e-payment facility, namely, 4.48, 4.69, 4.37, and 4.46, respectively. Moreover, the respondents often made transactions using e-payment services, as indicated by the mean of 4.18 . The respondents' answers as a whole regarding the MSME performance statement obtained a mean value of 4.33 . This is indicated by the statement of the increase in income, sales, and business production with a mean of 4.12, 4.17, and 4.11, respectively. In addition, the respondents' payments using e-payment services were already very fast and easy, indicated by the mean of each statement, namely, 4.65 and 4.62 .

The next analysis is to test the research hypothesis using the $t$-test, namely, by looking at the value of the $t$-statistic, which is compared to the t-table value of 1.64 .

Table 1. Research hypothesis testing.

\begin{tabular}{|c|c|c|c|c|}
\hline Research Hypothesis & t-statistic & $\begin{array}{l}\text { Original } \\
\text { Sample }\end{array}$ & p Values & Information \\
\hline Financial inclusion $\rightarrow$ MSME performance (H1) & 2.074 & 0.279 & 0.039 & Hypothesis is accepted \\
\hline $\begin{array}{l}\text { Moderating effect of the use of fintech e-payment on } \\
\text { the relationship of financial inclusion } \rightarrow \text { MSMEs } \\
\text { performance }(\mathrm{H} 2)\end{array}$ & 0.305 & 0.029 & 0.761 & Hypothesis is rejected \\
\hline
\end{tabular}

Table 2 depicts that the influence of FI (financial inclusion) and KI (MSME performance) resulted in a $t$-statistic of 2.074, which is greater than the $t$-table of 1.64. In other words, H0 was accepted. Therefore, it can be concluded that financial inclusion affected MSME performance. The value of the original sample was 0.279 , which indicated that financial inclusion had a positive effect on MSME performance. This shows that public access to financial products such as banking products is one of the factors that can improve MSME performance. The respondents can access their bank accounts through banks/ATMs and their cell phones. Their access to bank accounts is very important; in this case, the access made is like financial transactions. The results of this study are consistent with research of Chauvet and Jaolin (2017), who stated that financial inclusion has an impact on company growth. In line with Indriyati (2020), financial inclusion also affects MSME performance. This indicates that the better the financial inclusion, the higher will be the level of MSME performance and vice versa. The research by Yanti (2019) also reveals that financial inclusion influences MSME performance.

In addition, Table 2 shows that the moderating effect of using fintech e-payment services and the relationship between financial inclusion and MSME performance had a $t$-statistic of 0.305 , 
and this value was below 1.64 , which means that $\mathrm{H} 0$ was rejected. Therefore, the use of fintech did not moderate the effect of financial inclusion on the MSME performance. The category of the moderating variable can be seen in the results of the $p$ value or alpha. The $p$ value obtained was below 0.005 or $5 \%$. If the $p$-value is above 0.005 , the relationship is considered insignificant. In Table 2, it can be seen that the p-value of the moderating effect is 0.761 , which means it was not significant because it was above 0.005 . In addition, the original sample value of the moderation relationship, which was 0.029 , indicated that the moderating variable had a positive effect on the relationship between financial inclusion and performance.

\section{CONCLUSION}

The data analysis results show that financial inclusion has a relationship with MSME performance. Financial inclusion encourages people to access financial products, and people can use their money more freely to make transactions wherever they are, in this case, making transactions in food and beverage businesses in Surabaya City. From the results of hypothesis testing, it was found that the variable use of fintech services did not moderate the relationship between financial inclusion and MSME performance, but it still had a positive, insignificant effect on this relationship. The use of fintech services is not visible because the majority of respondents already have bank accounts and use fintech e-payment services, so that the respondents are familiar with the existing system. Therefore, the effect of using this system does not have a significant impact on its performance.

\section{REFERENCES}

Agnello, L., Mallick, S. K., \& Sousa, R. M. (2012). Financial reforms and income inequality. Economics Letter, 583-587.

Ardela, F. (2017, October 24). Teknologi finansial: Tengok dulu perkembangan fintech di Indonesia. From Finansialku: https://www.finansialku.com/perkembangan-fintech-di-indonesia/

Batunanggar, S. (2019). Fintech development and regulatory frameworks in Indonesia. Asian Development Bank Institute, 1-12.

Chauvet, L., \& Jaolin, L. (2017). Financial inclusion, bank concentration, and firm performance. World Development, 1-13.

Iman, N. (2018). Is mobile payment still relevant in the fintech era? Elsevier, 72-82.

Indriyati, N. (2020). Pengaruh inklusi keuangan dan literasi keuangan terhadap kinerja UMKM batik di kabupaten Tegal. Tegal: Universitas Pancasakti Tegal.

Kodan, A. S., \& Chhikara, K. S. (2013). A theoretical and quantitative analysis of financial inclusion and economic growth. sagepub, 103-133.

Kunt, A. D., \& Klapper, L. (2013). Measuring financial inclusion: Explaining variation in use of financial services across and within countries. Brookings Papers on Economic Activity, 279-340.

Leong, C., Tan, B., Xiao, X., Tan, F. T., \& Sun, Y. (2017). Nurturing a fintech ecosystem: The case of a youth microloan startup in China. International Journal of Information Management, 92-97.

Rahmi, M. (2018). Fintech for financial inclusion: Indonesia case. 1st International Conference on Economics, Business, Entrepreneurship, and Finance (ICEBEF 2018) (pp. 1-3). Indonesia: Atlantis Press.

Ramadhani, N. (2020, March 03). 6 manfaat fintech yang dapat dirasakan oleh banyak orang. From Akseleran: https://www.akseleran.co.id/blog/manfaat-fintech/

Ramadhani, P. I. (2020, August 24). Kurang literasi, ini tantangan besar kembangkan fintech di Indonesia. From Liputan6: https://www.liputan6.com/bisnis/read/4338030/kurang-literasi-ini-tantangan-besarkembangkanfintech-di-indonesia

Setiawan, M., Emvalomatis, G., \& Lansik, A. O. (2012). The relationship between technical efficiency and industrial concentration: Evidence from the Indonesian food and beverages industry. Journal of Asian Economics, $466-475$.

Setyadi, A. (2017, May 16). UMKM sulit dapat modal usaha, ini solusi BI. From detikfinance: https://finance.detik.com/berita-ekonomi-bisnis/d-3502490/umkm-sulit-dapat-modal-usaha-ini-solusi-bi

Soriano, M. A. (2017). Factors driving financial inclusion and financial performance in fintech new ventures: An empirical study. Singapore: Singapore Management University.

Yanti, W. I. (2019). Pengaruh inklusi keuangan dan literasi keuangan terhadap kinerja UMKM di kecamatan moyo utara. JURNAL MANAJEMEN DAN BISNIS, 1-10. 